\title{
Patient Simulator Sessions and Critical Thinking
}

Patricia K. Ravert

Brigham Young University - Provo, patricia-ravert@byu.edu

Follow this and additional works at: https://scholarsarchive.byu.edu/facpub

Part of the Other Nursing Commons

\section{Original Publication Citation}

Ravert, P. Patient simulator sessions and critical thinking. (2008). Journal of Nursing Education. 47(12), 557-562.

\section{BYU ScholarsArchive Citation}

Ravert, Patricia K., "Patient Simulator Sessions and Critical Thinking" (2008). Faculty Publications. 5272. https://scholarsarchive.byu.edu/facpub/5272 accepted for inclusion in Faculty Publications by an authorized administrator of BYU ScholarsArchive. For more information, please contact ellen_amatangelo@byu.edu. 


\title{
Patient Simulator Sessions and Critical Thinking
}

\author{
Patricia Ravert, PhD, RN
}

\begin{abstract}
The project purpose was to determine whether measures of critical thinking show differences between three groups (simulator, non-simulator, control) of baccalaureate nursing students. The second purpose was to determine the moderating effect of students' preferred learning style. All groups experienced a moderate to large effect size in critical thinking scores. The corrected model for the total scale gain score was statistically significant but not significant for learning style or group.
\end{abstract}

$\mathrm{M}$ any nursing programs are using patient simulation sessions to enhance student learning. Patient simulators are used in nursing curriculum with the belief that when the previously simulated situation is encountered in a reallife experience, the student will be

Received: July 13, 2006

Accepted: November 1, 2006

Dr. Ravert is Associate Professor, Associate Dean, and Nursing Learning Center and Clinical Simulation Laboratory Coordinator, Brigham Young University, Provo, Utah.

This project was funded by the Brigham Young University College of Nursing and the National League for Nursing/Medical Education Technologies, Incorporated, "Use of the Human Patient Simulator" Research Grant.

Please address correspondence to $\mathrm{Pa}$ tricia Ravert, PhD, RN, Associate Professor and Associate Dean, Brigham Young University, College of Nursing, 500D SWKT, Provo, UT 84602-5450; e-mail: patricia_ravert@ byu.edu. able to understand and successfully manage the situation. High-fidelity, computer-based patient simulators allow students to assess changeable heart sounds, breath sounds, and chest movement; experience cardiac monitoring; administer simulated medications; and observe physiological effects. The content of student sessions may include assessment, management of critical events, technical skills, care of patients with specific diseases or conditions, nursing interventions, pharmacology, and physiology, as well as advanced skills or airway management, resuscitation, and induction of anesthesia (Nehring, Ellis, \& Lashley, 2001; Nehring \& Lashley, 2004).

The Human Patient Simulator (HPS) marketed by Medical Education Technologies, Incorporated, is a computer-driven and gas-driven high-fidelity simulator. It can be programmed to simulate physiological changes in the cardiovascular, pulmonary, metabolic, and neurological systems. The simulator is programmed to physiologically respond as a real person would with a similar condition (i.e., a decrease in blood pressure and an increased heart rate with hemorrhage or shock). If those caring for the simulated patient deliver the appropriate care and interventions, such as hydration and medications, the physiological parameters improve. If the appropriate care and interventions are not delivered in a timely manner, parameters worsen and in some cases the simulated patient may die. The simulator can function using different patient profiles, underlying physiological settings, and health care scenarios. These computer-based simulators also allow the same patient and scenario to be experienced by multiple students or groups of students at different times.

A review of the literature in 2001 regarding simulation in health care education (nursing, medical, dental) yielded few quantitative studies, and none of these investigated the effects of using a high-fidelity patient simulator with nursing students (Ravert, 2002). However, since 2001, with the increasing use of patient simulators in nursing programs, researchers are investigating student perceptions of learning, usefulness, student satisfaction, and self-efficacy (Alinier, Hunt, Gordon, \& Harwood, 2006; Bearnson \& Wiker, 2005; Bremner, Aduddell, Bennett, \& VanGeest, 2006; Feingold, Calaluce, \& Kallen, 2004). Many educators think students' critical thinking may be enhanced by participation in patient simulation experiences; however, the nursing research to support this idea is lacking. Therefore, the primary purpose of this project was to determine whether measures of critical thinking (disposition, skills) show differences between three groups of baccalaureate nursing (BSN) students. Two groups participated in enrichment activities: one group participated in five patient scenarios using a high-fidelity patient simulator, and one group participated in five small group discussions regarding the patient scenarios. The third group served as the control group and received the regular education program, without enrichment activities. The second purpose was to determine 
the moderating effect of students' preferred learning style on critical thinking during enrichment activities.

\section{Literature Review}

Because many programs use simulation to enhance or teach critical thinking, and because participants' experiences with simulation may be influenced by their learning style, these concepts were reviewed in the literature. A discussion of each follows.

\section{Simulation}

Simulation is the imitation or reenactment of a condition or situation, or the representation of a behavior or characteristic by using another system. Simulation has been used extensively in the aviation industry and in medical education, as well as in nursing education to a lesser degree (Hotchkiss \& Mendoza, 2001). Nurse educators have used simulation to help students learn the cognitive and psychomotor skills necessary to perform nursing actions in a nonthreatening and safe environment (Bruce, Bridges, \& Holcomb, 2003; Chau et al., 2001; Jeffries, 2005; Jenkins \& Turick-Gibson, 1999; Peterson \& Bechtel, 2000; Rauen, 2001; Weis \& Guyton-Simmons, 1998). However, use of high-fidelity, full-body, computer-driven patient simulators may allow students to learn, practice, and improve higher-order cognition processes, such as critical thinking and reasoning.

High-fidelity simulations offer several advantages and disadvantages. Advantages of simulation for instructors include allowing the instructor to focus on a particular aspect of the patient situation and present common complications or rarely seen situations. Advantages for students include learning in a self-paced manner, developing higher-order thinking skills, and making mistakes without negative repercussions to the learner or to the patient (Fletcher, 1995; Friedrich, 2002; Helmreich \& Davies, 1997; Issenberg, Gordon, Gordon, Safford, \& Hart, 2001; Miller, 1987; Morton, 1997; Nehring \& Lashley, 2004; Ziv, Small, \& Wolpe, 2000). Disadvan- tages include the lack of realism in the simulation experience and patient responses; need for personnel to run the simulator; and the expense of the high-fidelity, computer-based simulator. Depending on the desired functionality and intended use, one adult simulator costs between $\$ 30,000$ and $\$ 175,000$.

\section{Critical Thinking}

Nursing education guidelines in the United States emphasize the importance of critical thinking. In fact, the National League for Nursing Accrediting Commission (2006) identified critical thinking as an essential skill in the nursing curriculum. The American Association of Colleges of Nursing (1998) stated critical thinking is one of the core competencies in the preparation of professional nurses. Critical thinking is a complex concept, without consensus in definition. Although there is no agreement on a universal definition, most definitions are similar (Adams, 1999; Bowles, 2000; Facione, Facione, \& Giancarlo, 1996; Frye, Alfred, \& Campbell, 1999; Gordon, 2000; Mangena \& Chabeli, 2005; Pless \& Clayton, 1993; ProfettoMcGrath, 2005; Scheffer \& Rubenfeld, 2000; Sedlak, 1997; Turner, 2005). Pless and Clayton (1993) noted that in the discipline of nursing, consensus regarding critical thinking skills includes interpretation, analysis, evaluation, inference, explanation, and self-regulation.

The American Philosophical Association sponsored a cross-disciplinary panel using a 2-year Delphi project to develop a concept of critical thinking (Facione, Facione, \& Sanchez, 1994). According to Facione et al. (1994), the consensus statement for critical thinking, developed by the panel, is:

We understand critical thinking to be purposeful, self-regulatory judgment which results in interpretation, analysis, evaluation, and inference as well as explanation of the evidential, conceptual, methodological, criteriological, or contextual considerations upon which judgment is based. (p. 2)

The work of the American Philosophical Association resulted in at least two critical thinking instruments. The California Critical Thinking Disposition Inventory (CCTDI) and the California Critical Thinking Skills Test (CCTST) were developed to assess critical thinking in college students. These instruments have also been used in studies with nursing students as participants (Beeken, 1997; Giddens \& Gloeckner, 2005; Profetto-McGrath, 2005; Stewart \& Dempsey, 2005).

Although critical thinking is essential to successful nursing education and practice, there is no consensus about the definition or how to measure the concept. Instruments measuring critical thinking disposition and skills are available but not specific to nursing students during their program of study. Therefore, the American Philosophical Association's critical thinking definition and instruments were used for this study. Many nurse educators think that practicing problem solving using simulation of patient cases and scenarios will increase critical thinking, but there is a gap in the research to support this belief. However, simulation, particularly high-fidelity simulation, may be a teaching strategy that allows students to practice and improve their critical thinking skills concurrently.

\section{Learning Style}

Learning style represents observable actions of perception and interaction during the learning situation or in the learning environment (Sandmire, Vroman, \& Sanders, 2000). It is a broad concept incorporating the particular strategies used in problem solving and determining answers to difficult questions. How an individual learns best may be labeled his or her preferred learning style. Preferred learning style may influence, either positively or negatively, performance in individual or group learning (Hartman, 1995).

Kolb (1999), who conceptualized learning as experiential and a cyclic process, developed an assessment to determine preferred learning styles (i.e., experiential or reflective). Students who prefer an experiential approach, such as simulation experiences, may improve their critical 
thinking more than those who prefer a reflective approach. Student preferred learning style was selected as a study variable because it may be a moderating factor in student learning when the patient simulator is used.

\section{Method \\ Design}

A pretest-posttest research design was used in this study. Two cohorts of 64 undergraduate BSN students in the first medical-surgical nursing course taken after the fundamentals course who were enrolled in a private university in the United States were invited to participate. After institutional review board approval was obtained, the project was explained to the students, consent obtained, and participants from the first cohort randomly assigned to one of two experimental groups.

Twenty-eight participants volunteered, 3 dropped due to "busyness" and "inability to meet schedule required by study." The two experimental groups included a non-HPS group ( $n=13$ ) that participated in the regular education process and five enrichment sessions (weekly 1-hour small group discussions regarding the assigned patient situation) and an HPS simulation group $(n=12)$ that participated in the regular education process and five enrichment sessions (weekly 1-hour experiences caring for a simulated patient, along with three other nursing students).

After the experiences, participants in the experimental groups also consented to interviews that were audiotaped and transcribed. The participants from the second cohort $(n=15)$ served as a control group by participating in the regular education process with no enrichment sessions.

The sample was nearly all White women with an average age of 21.25 (range $=20$ to 27). The self-reported participant grade point average was 3.65 on a 4 -point grade scale. Students were classified as juniors or seniors, according to the number of completed credit hours, but all had completed only 1 semester of the nursing program. Additional demo-

\begin{tabular}{|c|c|c|c|}
\hline \multicolumn{4}{|c|}{$\begin{array}{c}\text { TABLE } 1 \\
\text { Demographics }\end{array}$} \\
\hline & Non-HPS $(n=13)$ & $\operatorname{HPS}(n=12)$ & Control $(n=15)$ \\
\hline \multicolumn{4}{|l|}{ Gender } \\
\hline Female & 12 & 12 & 15 \\
\hline Male & 1 & 0 & 0 \\
\hline \multicolumn{4}{|l|}{ Academic year } \\
\hline Junior & 4 & 7 & 3 \\
\hline Senior & 9 & 5 & 12 \\
\hline Mean age (y) & 22.9 & 21.7 & 21.5 \\
\hline $\begin{array}{l}\text { Mean reported grade } \\
\text { point average }\end{array}$ & 3.67 & 3.71 & 3.61 \\
\hline \multicolumn{4}{|l|}{ Learning style } \\
\hline Diverging & $3(7.5 \%)$ & $2(5 \%)$ & $1(2.5 \%)$ \\
\hline Assimilating & $3(7.5 \%)$ & $4(10 \%)$ & $3(7.5 \%)$ \\
\hline Converging & $4(10 \%)$ & $4(10 \%)$ & $8(20 \%)$ \\
\hline Accommodating & $3(7.5 \%)$ & $2(5 \%)$ & $3(7.5 \%)$ \\
\hline
\end{tabular}

graphic data are reported in Table 1. Each participants' critical thinking was assessed twice, at the beginning of the study and after the enrichment sessions were over.

\section{Instruments}

The variables measured were critical thinking disposition, critical thinking skill, and preferred learning style.

The 75-item CCTDI used a 6-point Likert scale (agree-disagree) response format. Participants usually completed the instrument in 15 to 20 minutes. The instrument measures participants' disposition in seven concepts or subscales:

- Truth-seeking.

- Open-mindedness.

- Analyticity.

- Systematicity.

- Critical thinking self-confidence.

- Inquisitiveness.

- Cognitive maturity.

The instrument provides a score for each subscale, as well as a total score. Subscale scores range from 10 to 60 , and total scores range from 70 to 420 . Cronbach's alpha (internal consistency, as based on the average sample) is reported as 0.91 for the total scale and 0.71 to 0.80 for the subscales (Facione et al., 1996).
The CCTST is a 34-item multiplechoice instrument. Participants usually spent 30 to 45 minutes completing the instrument. It was developed to be discipline neutral and to measure participants' core critical thinking skills. Items are scored dichotomously (right or wrong) and obtained by summing the number of correct answers for each subscale as well as for the entire scale. The CCTST provides six scores: five subscale scores and an overall score. According to Facione, Facione, and Sanchez (1994), the first three subscales draw together the major core critical thinking skills identified in the American Philosophical Association Delphi study:

- Analysis.

- Evaluation.

- Inference.

The last two subscales capture the more traditional concept of critical thinking:

- Deductive reasoning.

- Inductive reasoning.

Each item on the subscale is assigned to one of the first three subscales. Thirty of the 34 items are reclassified as either inductive or deductive reasoning and scored accordingly. The analysis, evaluation, and inference subscale scores range from 0 to 14. Inductive and deductive reason- 
TABLE 2

Critical Thinking Effect Size by Group

\begin{tabular}{|c|c|c|c|}
\hline & Non-HPS $(n=13)$ & $\operatorname{HPS}(n=12)$ & Control $(n=15)$ \\
\hline \multicolumn{4}{|c|}{ California Critical Thinking Disposition Inventory } \\
\hline Prescore $S D$ & 15.63 & 24.23 & 29.81 \\
\hline Postscore mean increase & 5.33 & 9.84 & 14.90 \\
\hline Effect size & Moderate & Moderate & Large \\
\hline \multicolumn{4}{|c|}{ California Critical Thinking Skills Test } \\
\hline Prescore $S D$ & 8.57 & 8.94 & 3.87 \\
\hline Postscore mean increase & 9.29 & 7.40 & 1.85 \\
\hline Effect size & Large & Large & Moderate \\
\hline
\end{tabular}

\section{TABLE 3}

Analysis of Variance for Critical Thinking Disposition Total Scale Gain Scores

\begin{tabular}{lccccc}
\hline Source & $\boldsymbol{d f}$ & $\begin{array}{c}\text { Sum of } \\
\text { Squares }\end{array}$ & $\begin{array}{c}\text { Mean } \\
\text { Square }\end{array}$ & $\boldsymbol{F}$ & $\boldsymbol{p}$ \\
\hline Corrected model & 12 & 1981.59 & 165.13 & 1.138 & 0.37 \\
Learning style & 3 & 127.52 & 42.5 & 0.293 & 0.83 \\
Group & 2 & 18.62 & 9.3 & 0.064 & 0.94 \\
$\begin{array}{l}\text { Group by learning } \\
\text { style }\end{array}$ & 6 & 930.05 & 155 & 1.068 & 0.41
\end{tabular}

ing subscale scores range from 0 to 16 , and the total score ranges from 0 to 34 . Because critical thinking is a complex concept, the subscale scores should not be considered exact indicators of an individual's ability, but rather indicators of overall strength and weakness (Beckie, Lowry, \& Barnett, 2001; Facione \& Facione, 1998). Reliability, according to the test manual, is reported as a KR-20 (internal consistency) range of 0.68 to 0.80. Correlations with the GRE have been reported as 0.582 to 0.719 . Correlations with the SAT have been reported as 0.44 to 0.545 .

The 12-item Learning Style Inventory uses a sentence completion format. The instrument measures the degree to which the participant displays each of the learning styles, as defined by Kolb (1999). Raw scores, with a possible range of 12 to 48 , are used to determine the participants' learning style quadrant, including:
- Diverging.

- Assimilating.

- Converging.

- Accommodating.

Cronbach's alpha, internal consistency as based on $N=268$, is reported as between 0.73 and 0.88 for each of the scales.

\section{Data Analysis}

Data analysis was performed using SPSS, version 11.5. The three groups were compared using a general linear model procedure with two factors, group and learning style quadrant. The pretest score was included as a covariate. The dependent response variables for the general linear model were the gain scores for each participant $(\mathrm{Y}=$ postscore - prescore $)$. The effect size was also determined, and separate analyses were conducted for each instrument. The corrected model considered the pretest scores. The effect size for the enrichment activities was computed by determining the standard deviation of the pretest scores for each group for critical thinking instruments. The overall group effect was analyzed, as was the effect of learning style within groups.

\section{Results}

All groups experienced a moderate to large effect size in the critical thinking scores of disposition and skill, as noted in Table 2. The HPS group and the non-HPS group both experienced a moderate effect size in critical thinking disposition scores. The control group experienced a large effect size in CCTDI scores. Both experimental groups experienced a large effect size in CCTST scores, whereas the control group experienced a moderate effect size in CCTST scores.

The disposition gain scores of the CCTDI were positive for the total scale with a moderate or large effect size for all groups (Table 3). There was no statistically significant difference between groups, but there was limited power to detect the effect of group differences due to the small sample size.

The skills gain scores for the CCTST were positive for the total scale, as well as for the 5 subscales with a large effect size for the experimental groups and a moderate effect for the control group (Table 4). The corrected model for the total scale gain score (combination of the design and the prescore covariate) was statistically significant ( $p=0.000)$, but not significant for learning style or group. However, there was limited 
power to detect the effect of group or learning style differences due to the small sample size. Learning style did not account for the increase in scores, and thus was not a moderating factor in this study (Tables 3 and 4).

\section{Discussion}

Overall, critical thinking scores of disposition and skill increased for all groups. However, there was no statistically significant effect for group, as the sample size was small. The increase in critical thinking scores may not have been affected by the kind of enrichment activity but rather by maturity and time in school. The critical thinking disposition scores may not have increased as much as the critical thinking skill scores because critical thinking disposition is an ingrained trait and, thus, difficult to change over time. As learning style did not account for the increase in scores, it was not a moderating factor here.

Possible reasons for nonsignificant findings include the small sample size. Another possibility is that the HPS experience may not have added anything to an in-depth classroom case study discussion. The HPS experience had a different environment than case study discussion and required different attention priorities, such as completing the tasks of assessing the patient and intervening appropriately before the patient's condition worsened. These attention priorities and concepts may not have been measured with the instruments used in this study.

\section{Limitations}

Project limitations consisted of a small sample size, as well as participant characteristics, simulator issues, and instrument issues. Sample size is often a concern in nursing education research due to the small class size within institutions. With the small sample size, there was limited power to detect the effect of group or learning style differences. Another limitation is the homogeneity of the sample; participants came from one college, had high grade point averages, and were younger than the national average of

\begin{tabular}{|c|c|c|c|c|c|}
\hline \multicolumn{6}{|c|}{$\begin{array}{c}\text { Analysis of Variance for Critical Thinking Skills } \\
\text { Total Scale Gain Scores }\end{array}$} \\
\hline Source & $d f$ & $\begin{array}{l}\text { Sum of } \\
\text { Squares }\end{array}$ & $\begin{array}{l}\text { Mean } \\
\text { Square }\end{array}$ & $F$ & $p$ \\
\hline Corrected model & 12 & 2171.92 & 180.99 & 16.3 & $0.000^{*}$ \\
\hline Learning style & 3 & 32.37 & 10.78 & 0.97 & 0.421 \\
\hline Group & 2 & 51.67 & 25.84 & 2.33 & 0.117 \\
\hline $\begin{array}{l}\text { Group by learning } \\
\text { style }\end{array}$ & 6 & 42.5 & 6.92 & 0.62 & 0.71 \\
\hline${ }^{*}$ Significant at $\mathrm{p}<0.0$ & & & & & \\
\hline
\end{tabular}

nursing students and may not represent most nursing students. As participants were in classes and clinical experiences together, contamination between groups may have occurred. In this project, both experimental groups received personal attention, such as time to have questions answered and time to learn about the patient scenarios. This may have contaminated results regarding the benefits of simulation experiences.

Regarding simulation, one limitation often brought up by students is that the simulator is not a real patient and some patient factors or conditions are difficult to simulate. This decreases the reality of the scenario. In addition, sometimes the simulator does not respond as expected, which may be an equipment or operator issue, and can affect student experiences.

There were also issues with the instruments. The critical thinking instruments may not be measuring concepts related to the profession of nursing. Although these instruments have been used with nursing student participants, they do not measure content specific to the profession of nursing. The Learning Style Inventory has also been used with various disciplines, including nursing, but may not be accurate in measuring nursing students' learning styles.

\section{Conclusions and Recommendations}

Students from both enrichment activity groups indicated during later interviews that the experiences were helpful in a variety of ways. The HPS group participants stated the simulations were as close to the real thing as possible. Students said they did not think they would consistently come to the enrichment activities unless required. Therefore, perhaps students should be given a choice of the experiences (HPS, small group discussion, or nothing) to learn the information given that there were no differences related to critical thinking among the groups. Students who prefer an experiential learning style may select patient simulator experiences, whereas those who prefer reflective learning styles may choose discussion groups. In addition, some students may prefer to study independently or with selected classmates.

Future research should include replication with a larger, more diverse sample. From multiple sites, researchers also should explore the dimensions patient simulation experiences may offer that are not offered in classroom discussions. A qualitative study, including use of videotaping or vigilant field notes, may more accurately capture learning experiences. Another project may yield information necessary to select or develop appropriate instruments for nursing education studies measuring critical thinking and learning styles. Instructional design research that allows incorporation of findings into the next phase of research is suggested. Eventually, it would also be important to examine outcome measures, 
such as licensure examination pass rates or job performance related to high-fidelity simulation experiences.

\section{References}

Adams, B.L. (1999). Nursing education for critical thinking: An integrative review. Journal of Nursing Education, 38, 111-119.

Alinier, G., Hunt, B., Gordon, R., \& Harwood, C. (2006). Effectiveness of intermediate-fidelity simulation training technology in undergraduate nursing education. Journal of Advanced Nursing, 54, 359-369.

American Association of Colleges of Nursing. (1998). The essentials of baccalaureate education for professional nursing practice. Washington, DC: Author.

Bearnson, C.S., \& Wiker, K.M. (2005). Human patient simulators: A new face in baccalaureate nursing education at Brigham Young University. Journal of Nursing Education, 44, 421-425.

Beckie, T.M., Lowry, L.W., \& Barnett, S. (2001). Assessing critical thinking in baccalaureate nursing students: A longitudinal study. Holistic Nursing Practice, 15(3), 18-26.

Beeken, J.E. (1997). The relationship between critical thinking and self-concept in staff nurses and the influence of these characteristics on nursing practice. Journal of Nursing Staff Development, 13, 272-278.

Bowles, K. (2000). The relationship of critical-thinking skills and the clinicaljudgment skills of baccalaureate nursing students. Journal of Nursing Education, 39, 373-376.

Bremner, M.N., Aduddell, K., Bennett, D.N., \& VanGeest, J.B. (2006). The use of human patient simulators: Best practices with novice nursing students. Nurse Educator, 31, 170-174.

Bruce, S., Bridges, E.J., \& Holcomb, J.B. (2003). Preparing to respond: Joint trauma training center and USAF nursing warskills simulation laboratory. Critical Care Nursing Clinics of North America, 15, 149-162.

Chau, J.P., Chang, A.M., Lee, I.F., Ip, W.Y. Lee, D.T., \& Wootton, Y. (2001). Effects of using videotaped vignettes on enhancing students' critical thinking ability in a baccalaureate nursing programme. Journal of Advanced Nursing, 36, 112-119.

Facione, N.C., Facione, P.A., \& Sanchez, C.A. (1994). Critical thinking disposition as a measure of competent clinical judgment: The development of the California Critical Thinking Disposition Inventory. Journal of Nursing Education, 33, 345-350.

Facione, P.A., \& Facione, N.C. (1998). The California Critical Thinking Skills Test: CCTST test manual. Millbrae,
CA: California Academic Press.

Facione, P.A., Facione, N.C., \& Giancarlo, C.A. (1996). The California Critical Thinking Disposition Inventory: CCTDI test manual. Millbrae, CA: California Academic Press.

Feingold, C.E., Calaluce, M., \& Kallen, M.A. (2004). Computerized patient model and simulated clinical experiences: Evaluation with baccalaureate nursing students. Journal of Nursing Education, 43, 156-163.

Fletcher, J.L. (1995). AANA journal course: Update for nurses anesthetists-anesthesia simulation: A tool for learning and research. AANA Journal, 63, 6167

Friedrich, M.J. (2002). Practice makes perfect: Risk-free medical training with patient simulators. Journal of the American Medical Association, 288, 2808, 2811-2812.

Frye, B., Alfred, N., \& Campbell, M. (1999). Use of the Watson-Glaser critical thinking appraisal with BSN students. Nursing and Health Care Perspectives, 20, 253-255

Giddens, J., \& Gloeckner, G.W. (2005). The relationship of critical thinking to performance on the NCLEX-RN. Journal of Nursing Education, 44, 85-89.

Gordon, J.M. (2000). Congruency in defining critical thinking by nurse educators and non-nurse scholars. Journal of Nursing Education, 39, 340-351.

Hartman, V.F. (1995). Teaching and learning style preferences: Transitions through technology. VCCA Journal, $9(2), 18-20$

Helmreich, R.L., \& Davies, J.M. (1997). Anaesthetic simulations and lessons to be learned from aviation. Canadian Journal of Anesthesia, 44, 907-912.

Hotchkiss, M.A., \& Mendoza, S.N. (2001). Update for nurse anesthetists. Part 6. Full-body patient simulation technology: Gaining experience using a malignant hyperthermia model. AANA Journal, 69, 59-65.

Issenberg, S.B., Gordon, M.S., Gordon, D.L., Safford, R.E., \& Hart, I.R. (2001). Simulation and new learning technologies. Medical Teacher, 23, 16-23.

Jeffries, P.R. (2005). A framework for designing, implementing, and evaluating simulations used as teaching strategies in nursing. Nursing Education Perspectives, 26, 96-103.

Jenkins, P., \& Turick-Gibson, T. (1999). An exercise in critical thinking using role playing. Nurse Educator, 24(6), 11-14.

Kolb, D.A. (1999). Learning style inventory. Boston: Hay Group.

Mangena, A., \& Chabeli, M.M. (2005). Strategies to overcome obstacles in the facilitation of critical thinking in nursing education. Nurse Education Today, 25, 291-298.

Miller, M.D. (1987). Simulations in medical education: A review. Medical Teacher, 9, 35-41.
Morton, P.G. (1997). Using a critical care simulation laboratory to teach students. Critical Care Nurse, 17(6), 6669.

National League for Nursing Accrediting Commission. (2006). Accreditation manual with interpretive guidelines by program type for postsecondary and higher degree programs in nursing. New York: Author.

Nehring, W.M., Ellis, W.E., \& Lashley, F.R (2001). Human patient simulations in nursing education: An overview. Simulation and Gaming, 32, 194-204.

Nehring, W.M., \& Lashley, F.R. (2004) Current use and opinions regarding human patient simulators in nursing education: An international survey. Nursing Education Perspectives, 25, 244-248.

Peterson, M.J., \& Bechtel, G.A. (2000). Combining the arts: An applied critical thinking approach in the skills laboratory. NursingConnections, 13(2), 43-49.

Pless, B.S., \& Clayton, G.M. (1993). Clarifying the concept of critical thinking in nursing. Journal of Nursing Education, 32, 425-428.

Profetto-McGrath, J. (2005). Critical thinking and evidence-based practice. Journal of Professional Nursing, 21, 364-371.

Rauen, C.A. (2001). Using simulation to teach critical thinking skills. You can't just throw the book at them. Critical Care Nursing Clinics of North America, 13, 93-103.

Ravert, P. (2002). An integrative review of computer-based simulation in the education process. CIN: Computers, Informatics, and Nursing, 20, 203-208.

Sandmire, D.A., Vroman, K.G., \& Sanders, R. (2000). The influence of learning styles on collaborative performances of allied health students in a clinical exercise. Journal of Allied Health, 29, 143-149.

Scheffer, B.K., \& Rubenfeld, M.G. (2000). A consensus statement on critical thinking in nursing. Journal of Nurs ing Education, 39, 352-359.

Sedlak, C.A. (1997). Critical thinking of beginning baccalaureate nursing students during the first clinical nursing course. Journal of Nursing Education, $36,11-18$.

Stewart, S., \& Dempsey, L.F. (2005). A longitudinal study of baccalaureate nursing students' critical thinking dispositions. Journal of Nursing Education, $44,81-84$.

Turner, P. (2005). Critical thinking in nursing education and practice as defined in the literature. Nursing Education Perspectives, 26, 272-277.

Weis, P.A., \& Guyton-Simmons, J. (1998) A computer simulation for teaching critical thinking skills. Nurse Educator, 23(2), 30-33.

Ziv, A., Small, S.D., \& Wolpe, P.R. (2000). Patient safety and simulation-based medical education. Medical Teacher, $22,489-495$. 
Copyright of Journal of Nursing Education is the property of SLACK Incorporated and its content may not be copied or emailed to multiple sites or posted to a listserv without the copyright holder's express written permission. However, users may print, download, or email articles for individual use. 